\title{
A new report of Nocardiopsis valliformis strain OT1 from alkaline Lonar crater of India and its use in synthesis of silver nanoparticles with special reference to evaluation of antibacterial activity and cytotoxicity
}

\author{
Dnyaneshwar Rathod $^{1,2} \cdot$ Patrycja Golinska $^{1}$ (D) Magdalena Wypij $^{1} \cdot$ Hanna Dahm $^{1}$ • \\ Mahendra Rai ${ }^{2}$
}

Received: 15 January 2016 / Accepted: 3 June 2016 / Published online: 9 June 2016

(C) The Author(s) 2016. This article is published with open access at Springerlink.com

\begin{abstract}
The authors report the biological synthesis of silver nanoparticles (AgNPs) by alkaliphilic actinobacterium Nocardiopsis valliformis OT1 strain isolated for the first time from Lonar crater, India. The primary detection of silver NPs formation was made by colour change from colourless to dark brown and confirmed by UV-Vis spectrum of AgNPs at $423 \mathrm{~nm}$, specific for AgNPs. Further, AgNPs were characterized by nanoparticle tracking analysis, Zeta sizer, Fourier transform infrared spectroscopy (FTIR) and transmission electron microscopy (TEM) analyses. FTIR analysis showed the presence of proteins as capping agent. TEM analysis revealed the formation of spherical and polydispersed AgNPs within the size range of 5-50 nm. The antimicrobial activity of silver nanoparticles against Escherichia coli, Klebsiella pneumoniae, Pseudomonas aeruginosa, Staphylococcus aureus and Bacillus subtilis was evaluated. The AgNPs showed the maximum antibacterial activity against $B$. subtilis (Gram positive) and the minimum against $E$. coli (Gram negative). The minimal inhibitory concentration values of AgNPs for the tested bacteria were found to be in the range of $30-80 \mu \mathrm{g} / \mathrm{mL}$. The AgNPs demonstrated higher antibacterial activity against all the bacteria tested as compared with the commercially available antibiotics. The cytotoxicity of biosynthesized AgNPs against in vitro human cervical cancer cell line (HeLa) demonstrated a dose-response activity. The $\mathrm{IC}_{50}$
\end{abstract}

Patrycja Golinska golinska@umk.pl

1 Department of Microbiology, Nicolaus Copernicus University, Lwowska 1, 87100 Toruń, Poland

2 Nanobiotechnology Lab, Department of Biotechnology, SGB Amravati University, Amravati, Maharashtra 444602, India value was found to be $100 \mu \mathrm{g} / \mathrm{mL}$ of AgNPs against cancer HeLa cell line.

Keywords Alkaliphilic actinobacteria $\cdot$ Biosynthesis . Silver nanoparticles $\cdot$ Antibacterial activity $\cdot$ Cytotoxicity

\section{Introduction}

Nowadays, the multidrug resistance in microbes is becoming a global problem, which is the leading cause of human death [1-8]. Therefore, there is a need to search for efficient, safe and affordable antimicrobials to tackle the problem [7]. Since ancient times, silver and its compounds are being used as antimicrobial agents in diseases caused by bacteria, fungi and viruses [9-12]. The potential antibacterial activity of silver nanoparticles (AgNPs) against Grampositive and Gram-negative bacteria including multidrug resistant strains was reported by many researchers [13-16]. The formation of biofilm by bacteria is a major threat to the health. Such bacteria are embedded in a complex polymer matrix and develop resistance to the antibiotics. The biofilms protects the bacterial cells as compared to the free living cells. There are various reports on role of AgNPs against microbial biofilm [13, 17, 18].

Similarly, Gandhiraj et al. [19] reported a significant anticancer activity of biosynthesized silver nanoparticles against breast cancer cell line MCF-7. The authors suggested that the synthesized AgNPs can be used to develop potential anticancer agent and active pharma molecule. Manivasagan et al. [20] also found cytotoxic effect of AgNPs against HeLa cancer cell line. Supraja and Arumugam [21] analysed cytotoxic effect of AgNPs and reported that cytotoxicity increased at higher concentrations. AgNPs demonstrated higher toxicity to 
microorganisms, while showed lower toxicity to mammalian cells as compared with other metals [22].

Biological synthesis of silver nanoparticles by different microorganisms such as bacteria [23-26], fungi [7, 27]; algae [28-30], plants [31-34], actinomycetes [15, 20, 35] and myxobacteria [36] has been attempted by many researchers. Among these organisms, the synthesis of nanoparticles by actinobacteria has been less known [37]. The method of biosynthesis is easy and eco-friendly. The actinobacteria are the producers of medicinally important bioactive compounds, mainly antibiotics, and those isolated from extreme and unexplored environments are predicted to be a rich source of novel antimicrobial agents [38].

Lonar Lake is located at Lonar in Buldhana district, Maharashtra, India, which was created by a meteor impact during the Pleistocene epoch. This lake, which lies in a basalt impact structure, is both saline and alkaline in nature $[39,40]$.

New species of Nocardiopsis, viz., N. valliformis HBUM 20028 (T), was isolated and described for the first time by Yang et al. [41]. We isolated a new strain of Nocardiopsis valliformis OT1 from Lonar crater, Maharashtra, India.

The present study was aimed to: (1) isolate and identify a new strain of Nocardiopsis valliformis OT1 from extreme habitat of alkaline Lonar crater; (2) use $N$. valliformis OT1 strain for biogenic synthesis of silver nanoparticles; and (3) assess antibacterial and cytotoxic activity.

\section{Materials and methods}

\section{Isolation of $N$. valliformis OT1 strain}

The actinobacterium $N$. valliformis OT1 strain was isolated from soil collected from the rim of Lonar Crater Lake located at Lonar in Buldhana district, Maharashtra, India, by the serial dilution method described by Golinska et al. [42] on the Starch Casein Agar (SCA, [43]) supplemented with $5 \% \mathrm{NaCl}$, at $\mathrm{pH} 8.5$.

The $\mathrm{pH}$ of collected Lonar Lake soil was found to be 10.4. The isolate was maintained on halophilic nutrient agar $(5 \mathrm{~g}$ yeast extract, $10 \mathrm{~g}$ casitone, glucose $5 \mathrm{~g}$ and $60 \mathrm{~g} \mathrm{NaCl}$ [44]) slants at room temperature and as suspensions of mycelial fragments and spores in $20 \%$ glycerol (v/v) at $-80^{\circ} \mathrm{C}$ for further study. The $N$. valliformis OT1 strain grew in the presence of $5-15 \%(\mathrm{w} / \mathrm{v}$ ) sodium chloride and from $\mathrm{pH} 7.0$ to 12.0 (all growth tests were carried out on halophilic nutrient agar).

\section{Molecular identification and phylogenetic analysis of $N$. valliformis OT1 strain}

The actinobacterium $N$. valliformis OT1 strain was identified on the basis of 16S rRNA gene sequence. DNA was isolated from biomass harvested following growth of the isolate at $27{ }^{\circ} \mathrm{C}$ for 7 days in ISP2 broth, $\mathrm{pH}$ 5.5 [45]. DNA was extracted using DNA extraction kit (Sigma) according to manufacturer's protocol, albeit with lysozyme at $45 \mathrm{mg} / \mathrm{mL}$ and incubation overnight at $37^{\circ} \mathrm{C}$. The PCR amplification of the $16 \mathrm{~S}$ rRNA gene was performed in a $100-\mu \mathrm{L}$ reaction mixture containing $8 \mu \mathrm{L}$ template DNA (100 ng), $10 \mu \mathrm{L}$ PCR buffer (Bioline), $2 \mu \mathrm{L}$ of each PCR primer (p27F, p1525R, each $10 \mathrm{mM}$ [46], $3.2 \mu \mathrm{L}$ dNTP mix (12.5 mM; Bioline), $6 \mu \mathrm{L} \mathrm{MgCl} 2$ (50 mM; Bioline), $2 \mu \mathrm{L} 5 \mathrm{U}$ Taq DNA polymerase (Bioline) and $66.8 \mu \mathrm{L}$ sterile MilliQ water. The PCR amplifications were made with an initial denaturation step at $95{ }^{\circ} \mathrm{C}$ for $1 \mathrm{~min}$, followed by 30 cycles of denaturation at $95{ }^{\circ} \mathrm{C}$ for $1 \mathrm{~min}$, annealing for $1 \mathrm{~min}$ at $55^{\circ} \mathrm{C}$ and an extension at $72{ }^{\circ} \mathrm{C}$ for $1 \mathrm{~min}$; following these procedures there was a final extension step of $72{ }^{\circ} \mathrm{C}$ for $5 \mathrm{~min}$. The amplified product was purified using PCR purification kit (Qiagen). The sequencing reactions were carried out by sequencing service of Institute of Biochemistry and Biophysics Polish Academy of Sciences, Warsaw, Poland.

The search for the closest phylogenetic neighbours based on 16S rRNA gene similarity was performed using the EzTaxon server (http://eztaxon-e.ezbiocloud.net/, [47]). Phylogenetic analyses were carried out using MEGA 6 [48] and PHYML [49] software packages. Phylogenetic trees based on the aligned sequences were inferred using the neighbour-joining [50], the maximum-likelihood [51], maximum-parsimony [52] tree-making algorithms. The root position of the unrooted tree was estimated using the 16S rRNA gene sequence of Streptomonospora nanhaiensis $12 \mathrm{~A} 09^{\mathrm{T}}$.

\section{Synthesis of silver nanoparticles (AgNPs) from $N$. valliformis OT1 strain}

$N$. valliformis OT1 strain was grown in $250-\mathrm{mL}$ Erlenmeyer flasks containing $100 \mathrm{~mL}$ halophilic nutrient broth ( $\mathrm{pH} 8.5)$ and incubated in the orbital shaker (150 rpm) at $27 \pm 1{ }^{\circ} \mathrm{C}$ for 8 days. The biomass was harvested by centrifugation at $6000 \mathrm{~g}$ for $10 \mathrm{~min}$ and washed thrice with sterile distilled water to remove the attached medium components. Then, the biomass was resuspended in $100 \mathrm{~mL}$ sterilized distilled water and incubated at $27 \pm 1{ }^{\circ} \mathrm{C}$ for $48 \mathrm{~h}$. Thereafter, the biomass was filtered through Whatman filter paper no. 1 in order to obtain cell-free filtrate. Later, the filtrate was additionally harvested by centrifugation and treated with $1 \mathrm{mM}$ silver nitrate solution, and kept at room temperature for 2-3 days. The supernatant (without silver nitrate) was used as control. The synthesized AgNPs were collected by centrifugation $(12,000 \mathrm{~g}$ for $30 \mathrm{~min})$. After 
centrifugation, the supernatant was removed and the AgNPs were dried at $40{ }^{\circ} \mathrm{C}$ overnight. The mass of dried silver nanoparticles was estimated in milligrams. For further studies nanoparticles were dissolved in sterile distilled water/broth to obtain desired concentrations.

\section{Characterization of silver nanoparticles}

\section{Visual detection}

After treatment of cell filtrate with silver nitrate, the preliminary detection of biosynthesized silver nanoparticles was carried out by visual observation of colour change from colourless to dark brown, which indicates the formation of Ag-nanoparticles.

\section{$U V$-visible spectroscopy analysis}

Absorption spectrum of the reaction mixture was measured between 200 - and $800-\mathrm{nm}$ wavelength range by UV-Vis spectrophotometer (NanoDrop ND-2000, Thermo Scientific, USA).

\section{Zeta potential analysis}

To understand the stability of biosynthesized silver nanoparticles, the zeta potential was measured. Nanoparticle samples $(25 \mu \mathrm{L})$ were diluted 10 times and then sonicated for $15 \mathrm{~min}$ at $20 \mathrm{~Hz}$. The mixture was filtered through $0.22-\mu \mathrm{m}$ filter and used for zeta potential measurement by Malvern Zetasizer 90 (ZS 90, Malvern Instruments Ltd, UK).

\section{Fourier Transform Infrared Spectroscopy (FTIR) analysis}

To determine the biomolecules responsible for the reduction of silver ions and stabilization of AgNPs in the solution, the FTIR analysis was carried out. The powder of synthesized AgNPs was combined with dry $\mathrm{KBr}$ in the ratio of 1:100. AgNPs were characterized by FTIR spectroscopy (PerkinElmer FTIR-2000, USA) in the range 4000$400 \mathrm{~cm}^{-1}$ at a resolution of $4 \mathrm{~cm}^{-1}$.

\section{Nanotracking analysis (NTA)}

The nanotracking analysis was performed to measure the average size of the synthesized AgNPs. Five microlitres of the nanoparticle sample was diluted with $2 \mathrm{~mL}$ of nuclease-free water, then injected into the sample chamber and observed through camera coupled with the nanoparticle tracking analyser NanoSight LM20 (Malvern Instruments Ltd, UK).

\section{Transmission Electron Microscopy (TEM) Analysis}

The size and morphology of the AgNPs were analysed by FEI Tecnai F20 X-Twintool (Fei, USA) transmission electron microscopy operating at an acceleration voltage of $100 \mathrm{kV}$. The sample was prepared on a carbon-coated copper grids ( $400 \mu \mathrm{m}$ mesh size) by dropping a small amount of solution of AgNPs. The sample was then allowed to dry at room temperature prior to measurements. The obtained data were assessed by Statistica Software (StatSoft, USA).

\section{Antibacterial activity of AgNPs}

Activity of AgNPs individually and in combination with antibiotics against bacteria using disc diffusion method

The biosynthesized AgNPs from strain N. valliformis OT1 were screened against Gram-positive bacteria, namely Staphylococcus aureus (ATCC6338) and Bacillus subtilis (PCM2021 = ATCC 6633), and Gram-negative bacteria including Escherichia coli (ATCC8739), Pseudomonas aeruginosa (ATCC10145) and Klebsiella pneumoniae (ATCC700603) by disc diffusion method on Trypticase soy agar (TSA, Becton-Dickinson). The $100 \mu \mathrm{L}$ of bacterial inoculum $\left(1 \times 10^{6} \mathrm{CFU} / \mathrm{mL}\right)$ was spread on to the surface of medium with sterile spreader. Subsequently, sterile disc (Ø $5 \mathrm{~mm}$, Oxoid) impregnated with silver nanoparticles $(20 \mu \mathrm{L})$ and standard antibiotic discs (kanamycin $30 \mathrm{mcg} /$ disc, ampicillin $25 \mathrm{mcg} / \mathrm{disc}$ and tetracycline $30 \mathrm{mcg} / \mathrm{disc}$, Oxoid) were placed on to the surface of medium inoculated with tested bacteria. Similarly, the combined effects of each standard antibiotic and AgNPs were determined. Prior to study, the antibiotic discs were impregnated with a concentrated colloidal solution of silver nanoparticles $(20 \mu \mathrm{L})$. The cell-free filtrate was used as a control. The plates were incubated at $37{ }^{\circ} \mathrm{C}$ for $24 \mathrm{~h}$, and zones of bacterial growth inhibition were measured (in $\mathrm{mm}$ ). The assay was performed in triplicate.

Determination of MIC of antibiotics against tested bacteria

The minimum inhibitory concentration (MIC) is defined as the lowest concentration of chemicals that inhibits the growth of the organism. The MIC assays of antibiotics (ampicillin, kanamycin or tetracycline) were performed using Etest strips (BioMerieux) in the range of 0.016$256 \mu \mathrm{g} / \mathrm{mL}$ against bacterial isolates. The study was performed by diffusion method on Trypticase soy agar (TSA, Becton-Dickinson). The $100 \mu \mathrm{L}$ of bacterial inoculum $\left(1 \times 10^{6} \mathrm{CFU} / \mathrm{mL}\right)$ was spread on to the surface of the medium with sterile spreader. Subsequently, Etest stripe 
was placed onto the surface of inoculated agar medium and incubated for $24 \mathrm{~h}$ at $37^{\circ} \mathrm{C}$. Assay was performed in triplicate.

\section{Determination of the MIC of AgNPs against tested bacteria}

The MIC was determined by using 96-well culture plates. The synthesized AgNPs were screened for MIC by microtitre broth dilution method in triplicate. Trypticase soy broth was used as diluents for bacterial strains. The final concentration of bacteria in each well was $1 \times 10^{6} \mathrm{CFU} / \mathrm{mL}$. The different concentrations (from 10 to $100 \mu \mathrm{g} / \mathrm{mL}$ ) of AgNPs were used. The positive and negative controls were maintained. The microtitre plates were read at $450 \mathrm{~nm}$ on multimode reader (Biolog, USA) after incubation to determine the MIC values. Plates were incubated at $37^{\circ} \mathrm{C}$ for $24 \mathrm{~h}$.

\section{Activity of AgNPs against bacteria in combination with antibiotics by dilution plate method}

The MIC values of AgNPs from strain N. valliformis OT1 and commercial antibiotic were used to estimate accurate synergistic effect of AgNPs on antibiotic (kanamycin, ampicillin and tetracycline) activity. The assay was performed using 96-well culture plates in triplicate. The final concentration of bacteria in each well was $1 \times 10^{6} \mathrm{CFU} /$ $\mathrm{mL}$. The Trypticase soy broth (TSB, Becton-Dickinson) was used as diluent for bacterial strains, antibiotics and AgNPs. The positive and negative controls were maintained. The microtitre plates were read at $450 \mathrm{~nm}$ on multimode reader (Biolog, USA) after incubation to determine the bacterial growth inhibition (\%). Plates were incubated at $37^{\circ} \mathrm{C}$ for $24 \mathrm{~h}$.

\section{Cytotoxicity bioassay}

Cell viability was evaluated by the MTT colorimetric technique using human HeLa cancer cell line, which was seeded in 96-well tissue culture plates. The monolayer cell culture was trypsinized, and the cell count was adjusted to $3 \times 10^{5}$ cells $/ \mathrm{mL}$ using medium containing $10 \%$ newborn calf serum. To each well in microtitre plates, $100 \mu \mathrm{L}$ of diluted cell suspension was added and incubated $24 \mathrm{~h}$ to form the cell monolayer. The supernatant was then flicked off, and $25 \mu \mathrm{L}$ of AgNPs at final concentration 25, 50, 75 and $100 \mu \mathrm{g} / \mathrm{mL}$ was added to the cells in microtitre plate and incubated at $37{ }^{\circ} \mathrm{C}$ in $5 \% \mathrm{CO}_{2}$ incubator for $48 \mathrm{~h}$. The cells were periodically checked for granularity, shrinkage and swelling. The sample solution in wells was then flicked off, and $25 \mu \mathrm{L}$ of MTT (3-(4, 5-dimethylthiazolyl-2)-2,5diphenyltetrazolium bromide) dye was added to each well for reduction of MTT by metabolically active cells. The plates were gently shaken and incubated for $4 \mathrm{~h}$ at $37{ }^{\circ} \mathrm{C}$ in
$\mathrm{CO}_{2}$ incubator. The supernatant was removed and replaced with $100 \mu \mathrm{L}$ of DMSO for solubilization of the MTT crystals. The absorbance was measured using a microplate reader (Biolog, USA) at a wavelength of $570 \mathrm{~nm}$. First the percentage growth inhibition was calculated using following formula, $\%$ cell inhibition $=100-\{(\mathrm{At}-\mathrm{Ab}) /$ $(\mathrm{AcAb})\} \times 100$, where At $=$ Absorbance value of test compound, $\mathrm{Ab}=$ Absorbance value of blank, $\mathrm{Ac}=$ Absorbance value of control. Then, $\%$ of cell viability $=100 \%-\%$ of cell inhibition was calculated. The $\mathrm{IC}_{50}$ value was plotted by taking the concentration of AgNPs on X-axis versus percentage of cell viability on Y-axis.

\section{Statistical analysis}

To determine whether there are any significant differences among the activities of AgNPs, antibiotics and the combination of AgNPs and antibiotics, we applied 'oneway ANOVA' for the relative variability within above parameters.

\section{Results}

\section{Molecular identification and phylogenetic analysis of $N$. valliformis OT1 strain}

Nearly complete 16S rRNA gene sequence of $N$. valliformis OT1 strain (1430 nt; GenBank accession number: KU523974) was determined. Based on the EzTaxon-e analysis, $N$. valliformis OT1 strain was affiliated to the genus Nocardiopsis, being most closely related to $N$. valliformis DSM-45023 ${ }^{\mathrm{T}}(99.4 \%)$, N. exhalans $\mathrm{ES} 10.1^{\mathrm{T}}(99.4 \%)$ and N. metallicus $\mathrm{KBS6}^{\mathrm{T}}(99.4 \%)$ and showed 8,9 and $8 \mathrm{nt}$ differences per 1430, 1428 and 1430 locations, respectively. 16S rRNA gene sequence similarities between $N$. valliformis strain OT1 and other type strains of the genus Nocardiopsis were lower than $98.8 \%$. The phylogenetic trees based on 16S rRNA gene sequences showed that $N$. valliformis strain OT1 formed a distinct branch with $N$. valliformis DSM- $45023^{\mathrm{T}}$, N. exhalans ES10.1 ${ }^{\mathrm{T}}$ and $N$. metallicus $\mathrm{KBS6}^{\mathrm{T}}$, which was supported by a bootstrap value of $42 \%$ in the neighbour-joining tree (Fig. 1) and also recovered with the maximum-likelihood and maximum-parsimony algorithms.

\section{Characterization of AgNPs}

In the present study, silver nanoparticles (AgNPs) were synthesized by cell filtrate of actinobacterial $N$. valliformis OT1 strain which turned from colourless to dark brown after treatment with $1 \mathrm{mM} \mathrm{AgNO}_{3}$ (Fig. 2). Moreover, the biosynthesized Ag-nanoparticles were characterized by 


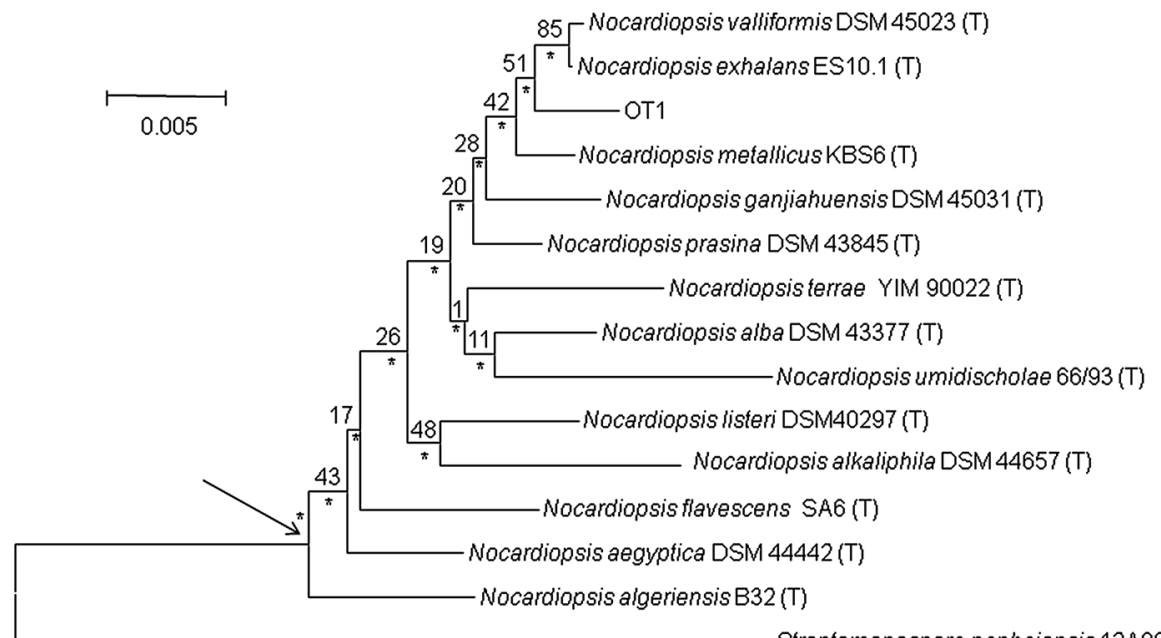

Fig. 1 Neighbour-joining tree based on nearly complete 16S rRNA gene sequences (1430 nt) showing relationships between the isolate N. valliformis and the type strains Nocardiopsis species. Asterisks indicate branches that were also found using the maximum-likelihood and maximum-parsimony tree-making algorithms. Numbers at

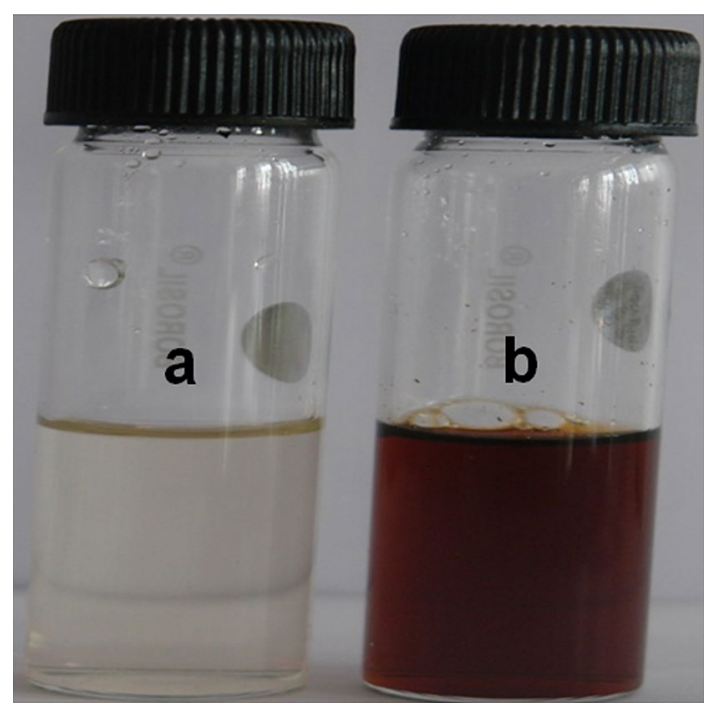

Fig. 2 Visual detection of silver nanoparticles synthesized from Nocardiopsis valliformis OT1 strain control (a) and experimental (b)

UV-Vis spectroscopy, which showed sharp narrow peak with a maximum absorbance at $423 \mathrm{~nm}$ (Fig. 3). The $25 \mathrm{mg}$ of AgNPs was obtained from $100 \mathrm{~mL}$ of cell-free filtrate treated with $1 \mathrm{mM} \mathrm{AgNO}_{3}$.

The zeta potential of silver NPs synthesized from $N$. valliformis OT1 strain was found to be $-17.1 \mathrm{mV}$ which exhibited the stability of synthesized nanoparticles (Fig. 4).

The FTIR spectroscopy in the range $4000-400 \mathrm{~cm}^{-1}$ revealed the varied peaks, which corresponded to different functional groups and indicated the presence of stabilizing the nodes are percentage bootstrap values based on 1000 re-sampled datasets. T type strain. Bar 0.005 substitutions per nucleotide position. The root position of the tree was determined using Streptomonospora nanhaiensis $12 \mathrm{~A} 09^{\mathrm{T}}$ as outgroup

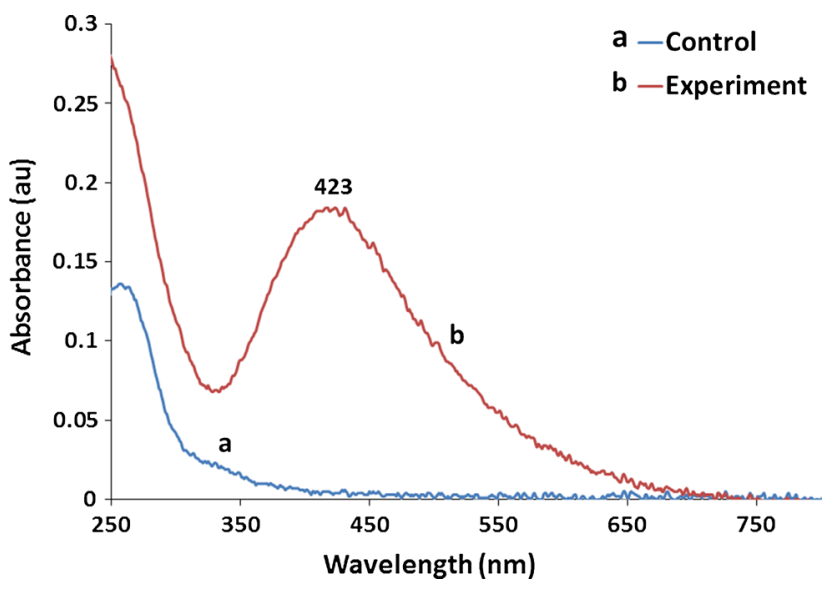

Fig. 3 UV-Vis spectrum of silver nanoparticles synthesized from Nocardiopsis valliformis OT1 strain control $(a)$ and experimental $(b)$

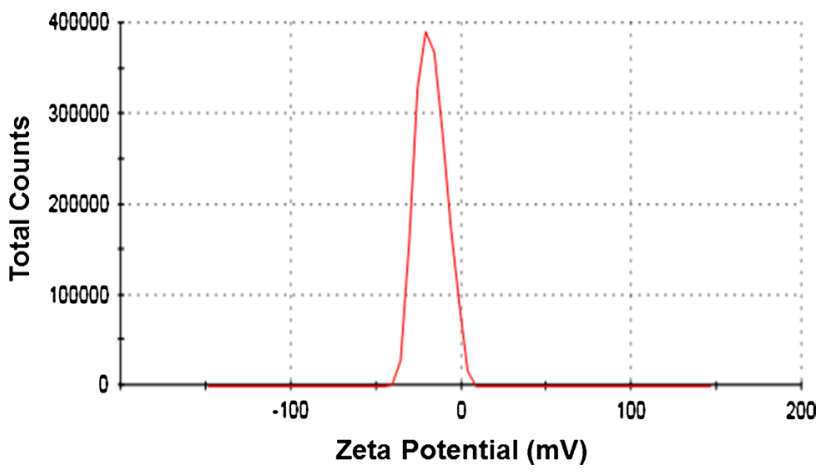

Fig. 4 Zeta potential graph of silver nanoparticles synthesized from OT1 strain $(-17.1 \mathrm{mV})$ at $\mathrm{pH} 7$ 
Fig. 5 FTIR analysis of silver nanoparticles synthesized from OT1 strain. Control (a) and experimental (b)
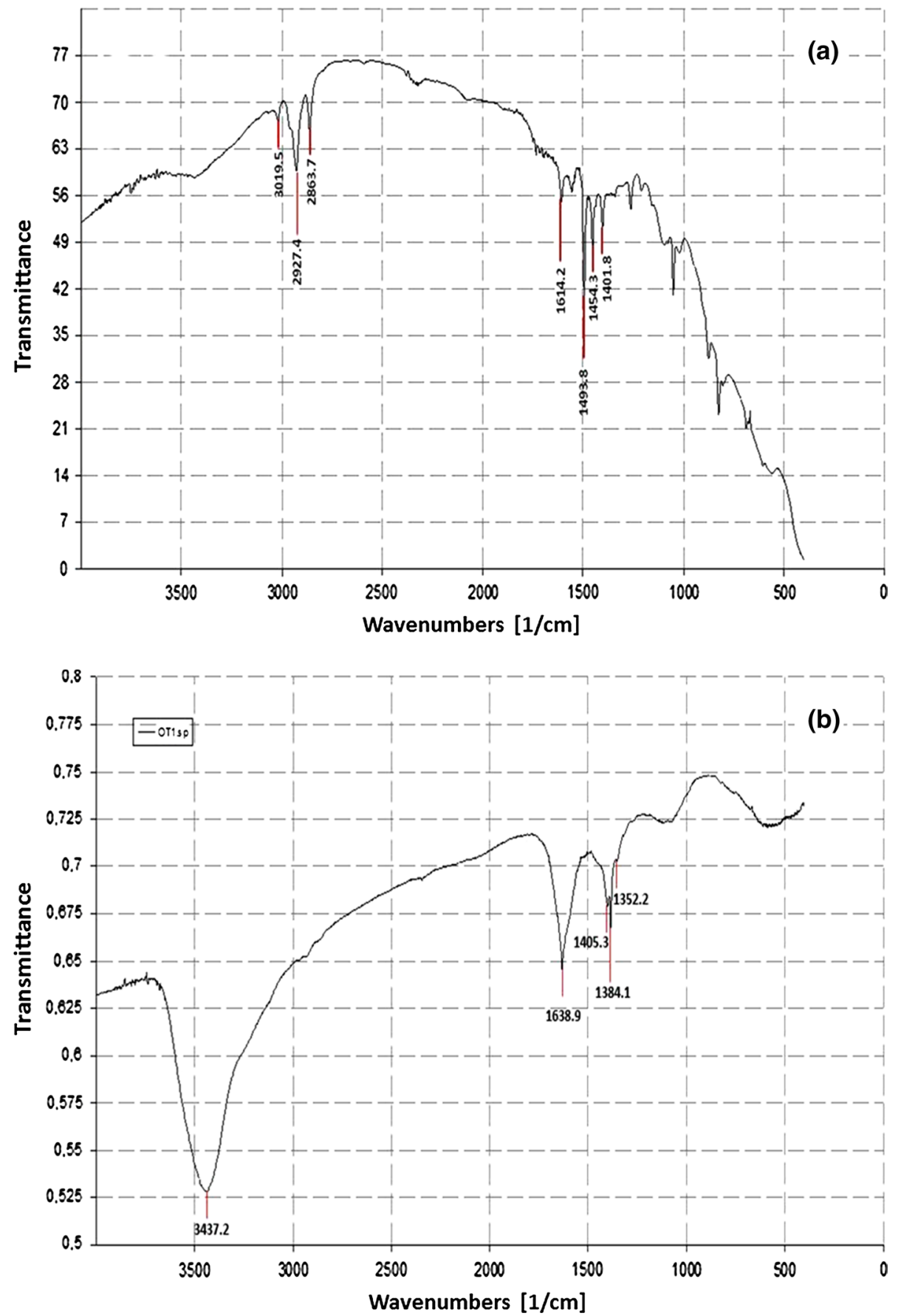

protein molecules on the surface of Ag-nanoparticles. In the present study, the Ag-nanoparticles synthesized from $N$. valliformis OT1 strain revealed absorbance peaks at 3437 , 1639, 1405, 1384 and $1352 \mathrm{~cm}^{-1}$ (Fig. 5).

The NTAs showed mean size of Ag-nanoparticles synthesized from isolate $N$. valliformis OT1 of $62( \pm 51) \mathrm{nm}$ (Fig. 6). The concentration of synthesized AgNPs was found to be $0.24 \times 10^{8}$ particles $/ \mathrm{mL}$.

The TEM analysis of Ag-nanoparticles from N. valliformis OT1 strain showed the presence of spherical and polydispersed nanoparticles in the size range of 5-50 nm (Fig. 7). The biosynthesized Ag-nanoparticles were also found as aggregates at some places.

\section{In vitro activity of biogenic AgNPs against tested bacteria}

The silver nanoparticles synthesized from $N$. valliformis were screened for its antibacterial activity against Escherichia coli (ATCC8739), Staphylococcus aureus 


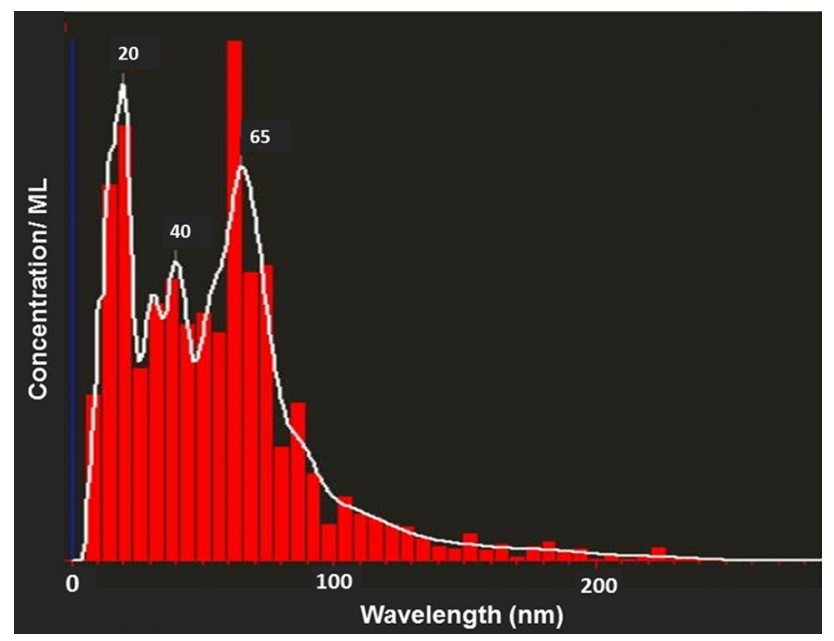

Fig. 6 NTA of silver nanoparticles synthesized from Nocardiopsis valliformis OT1 strain

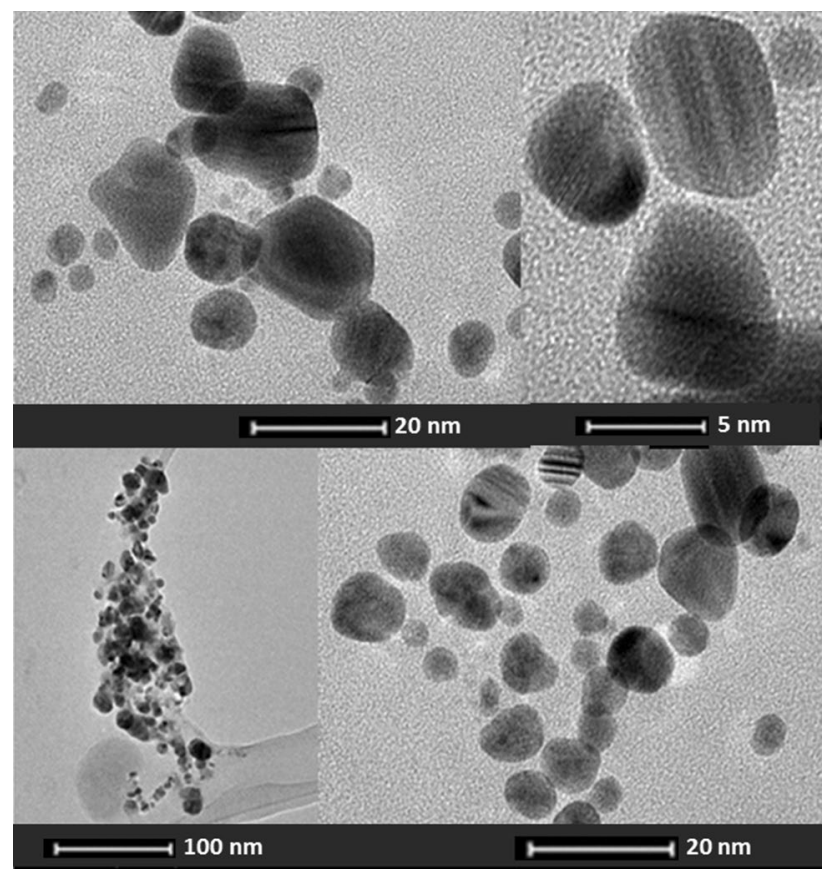

Fig. 7 Transmission electron micrograph and selected area diffraction pattern of silver nanoparticles synthesized from Nocardiopsis valliformis OT1 strain

(ATCC6338), Klebsiella pneumoniae (ATCC700603), Pseudomonas aeruginosa (ATCC10145) and Bacillus subtilis (PCM2021).

In the preliminary studies using disc diffusion method the Ag-nanoparticles showed maximum antibacterial activity against $B$. subtilis $(13.66 \mathrm{~mm})$, followed by $S$. aureus $(12.16 \mathrm{~mm})$, P. aeruginosa $(11 \mathrm{~mm}), K$. pneumoniae $(10.16 \mathrm{~mm})$ and E. coli $(9.66 \mathrm{~mm})$ (Table 1). The synergistic effect of silver NPs with antibiotics was also studied against above bacteria. The results of synergistic effects of the different antibiotics combined with synthesized AgNPs are shown in Table 1. Generally, the synergistic effect of AgNPs in combination with antibiotics was found to be with all tested antibiotics (with exception of AgNPs and ampicillin against Pseudomonas aeruginosa). The most interesting observations were noticed against $K$. pneumoniae and $P$. aeruginosa, which were resistant to antibiotics alone (ampicillin and kanamycin, respectively), but sensitive when antibiotics were combined with synthesized Agnanoparticles (Table 1).

The minimum inhibitory concentration (MIC) of biosynthesized Ag-nanoparticles was screened against all the tested bacteria. The MIC values of silver NPs were found to be in the range of $30-80 \mu \mathrm{g} / \mathrm{mL}$ (Table 2).

The results of synergistic effect of AgNPs with antibiotics using plate dilution method are presented in Table 2 . The maximum synergistic effect was observed for ampicillin and kanamycin when combined with AgNPs against Pseudomonas aeruginosa (41.92 and $35.8 \%$, respectively, higher bacterial growth inhibition than AgNPs used individually). Significant enhancement of bacterial growth inhibition was observed in the presence of AgNPs and kanamycin against Pseudomonas aeruginosa $(>8 \%)$.

\section{Cytotoxicity bioassay}

The in vitro cytotoxic activity of bioreduced AgNPs from $N$. valliformis OT1 strain was screened against cancer HeLa cell line. Encouragingly, AgNPs having concentrations of $25,50,75$ and $100 \mu \mathrm{g} / \mathrm{mL}$ showed 19.87, 30.72, 45.18 and $52.40 \%$ inhibition against cancer HeLa cell line, respectively (Fig. 8).

\section{Discussion}

Since Yang et al. [41] have reported new species of $N$. valliformis from alkaline lake of China, it is a first report on isolation of alkaliphilic actinobacterium Nocardiopsis valliformis OT1 strain from Lonar crater of Central India and its application in synthesis of AgNPs and antibacterial activity against bacterial pathogens [41].

The synthesis of AgNPs was studied after the treatment of cell-free filtrate with silver nitrate solution. The reduction of Ag ions into AgNPs is indicated by the change in colour from colourless to dark brown and the absorbance property of AgNPs at about $420 \mathrm{~nm}$ of wavelength. The presence of specific peak is due to the surface plasmon resonance property of noble metal nanoparticles [14, 16, 53].

The zeta potential is a measure of the electrostatic potential on the surface of the nanoparticles and is related to the electrophoretic mobility and stability of colloidal 
Table 1 Antibacterial activity of AgNPs synthesized from Nocardiopsis valliformis strain OT1 and its synergistic effect with antibiotics ( $\varnothing$ of disc $5 \mathrm{~mm}$ )

\begin{tabular}{|c|c|c|c|c|c|c|c|}
\hline \multirow[t]{2}{*}{ Bacteria } & \multirow[t]{2}{*}{ AgNPs } & \multicolumn{2}{|l|}{ Kanamycin } & \multicolumn{2}{|l|}{ Ampicillin } & \multicolumn{2}{|l|}{ Tetracycline } \\
\hline & & A & $\mathrm{A}+\mathrm{AgNPs}$ & A & $\mathrm{A}+\mathrm{AgNPs}$ & A & $\mathrm{A}+\mathrm{AgNPs}$ \\
\hline Escherichia coli ATCC8739 & $9.66 \pm 0.57$ & $14.66 \pm 1.15$ & $15.33 \pm 0.57$ & $16 \pm 0.57$ & $21.66 \pm 0.57$ & $19.33 \pm 0.76$ & $22.33 \pm 0.57$ \\
\hline Klebsiella pneumoniae АТCC700603 & $10.16 \pm 1.04$ & NI & $10.33 \pm 0.57$ & NI & $6 \pm 0$ & $11.83 \pm 0.28$ & $13.83 \pm 0.28$ \\
\hline Pseudomonas aeruginosa ATCC10145 & $11 \pm 1$ & NI & $10 \pm 0$ & $11.83 \pm 0.28$ & $9.83 \pm 0.28$ & $11.16 \pm 0.76$ & $16.16 \pm 1.04$ \\
\hline Staphylococcus aureus ATCC6338 & $12.16 \pm 1.25$ & $15.83 \pm 0.28$ & $16.83 \pm 0.28$ & $33.33 \pm 1.52$ & $40.5 \pm 0.5$ & $26.5 \pm 0.5$ & $28.83 \pm 1.04$ \\
\hline Bacillus subtilis PCM2021 & $13.66 \pm 0.57$ & $17.22 \pm 0.26$ & $19.5 \pm 0.5$ & $16.33 \pm 1.04$ & $18.25 \pm .05$ & $30.33 \pm 0.57$ & $32.5 \pm 0.5$ \\
\hline
\end{tabular}

Inhibition zones in diameter $(\mathrm{mm})$

Mean value is significantly different at $p \leq 0.05$

Values expressed in mean $\pm \mathrm{SD}$

A, antibiotic; AgNPs, silver nanoparticles; NI, no inhibition

suspension of nanoparticles [54]. It has been reported that the particles with higher negative or positive zeta potential value possess a force to repel each other and do not form aggregates. Unlike these with low zeta potential value, which has no force to avoid particles coming together, particles form a bigger particle as aggregation [55]. Our findings are similar to results by Gaikwad et al. [56] and Rai et al. [55] who reported zeta potential value range from -5.31 to $-15.8 \mathrm{mV}$ of mycogenic AgNPs.

To understand the contribution of biomolecules responsible for the reduction of the $\mathrm{Ag}^{+}$ions into $\mathrm{Ag}$ nanoparticles and the presence of capping agents over the bioreduced AgNPs responsible for stabilization of AgNPs, the FTIR spectroscopy was performed. The absorbance band at $3437 \mathrm{~cm}^{-1}$ can attribute to the vibrations of amino groups $(\mathrm{N}-\mathrm{H})$ related to the presence of peptides $[7,16,57]$. However, the peak at $1639 \mathrm{~cm}^{-1}$ may be because of carboxylic group $(\mathrm{C}=\mathrm{O})$ stretching. Similarly, the absorbance at $1405 \mathrm{~cm}^{-1}$ can be assigned to $\mathrm{C}-\mathrm{H}$ asym. deformation vibration [20]. In addition, the peak at $1384 \mathrm{~cm}^{-1}$ is associated with $\mathrm{CH}_{3}$ sym. bending and at $1352 \mathrm{~cm}^{-1}$ is resemblance to the $\mathrm{C}-\mathrm{H}$ deformation vibration [58]. From the above results, it is assumed that capping agent as proteins binds to silver NPs. Gole et al. [59] reported that proteins are responsible for binding to silver nanoparticles by the electrostatic attraction of negatively charged carboxylate groups present in the protein secreted by fungus. Consequently, the AgNPs become stable by proteins [59].

The average size of biosynthesized Ag-nanoparticles was measured by nanoparticle tracking analysis (NTA). NTA of AgNPs is based on light scattering and Brownian motion properties in order to obtain the good sizing accuracy and relatively narrow distributions from monodispersed samples [60]. The similar size of silver nanoparticles $(68.1 \mathrm{~nm})$ was found by Chauhan et al. [61] who studied Ag-nanoparticles synthesized from Streptomyces sp.
The TEM analysis showed that the actinobacterial strain $N$. valliformis OT1 was capable of synthesizing small-sized AgNPs. The present observations were found to be similar to other previous reports $[20,62,63]$ who found spherical AgNPs with some aggregations. The synthesis of smallsized $(5-40 \mathrm{~nm})$ and spherical silver nanoparticles was also reported by Sukanya et al. [64] who studied actinomycete culture of Streptomyces sp. II isolated from heavy metalpolluted and non-polluted areas in India. The difference in size of AgNPs analysed by TEM and NTA is due to the fact that TEM analyses reveal exact size and image of the metal nanoparticles as the beam of electrons used. It transmits electrons through an ultrathin specimen, which interacts with the sample, whereas in the NTA hydrodynamic radius is calculated, which is always larger. Therefore, the size measurement results using NTA are bigger when compared to TEM.

The mechanisms of antibacterial effect of silver nanoparticles are still unclear. The most widely known mechanism of AgNPs is the inhibition of the enzymatic function of some proteins by binding to the thiol groups of $\mathrm{L}$-cysteine [65]. It is claimed that AgNPs promote the permeability of the bacterial membrane and disrupt the membrane integrity $[20,22,66]$ which are also thought to be responsible for the antibacterial effect. Some studies showed that silver can bind to DNA, which increases the decomposability of genome DNA [67]. Silver NPs may also inactivate the respiratory chain and be cause of hydroxyl radicals' formation [65].

Depending on the size of AgNPs, its large surface area comes in contact with bacterial cell $[2,7,68]$. The smaller the size of silver nanoparticles, the larger the surface area to volume ratio, and hence obviously the bactericidal activity of silver nanoparticles is affected by the size of nanoparticles. Panacek et al. [68] studied the bactericidal activity based on the size of nanoparticles (27, 37, 46 and $52 \mathrm{~nm})$ and observed that nanoparticles having $25 \mathrm{~nm}$ showed 


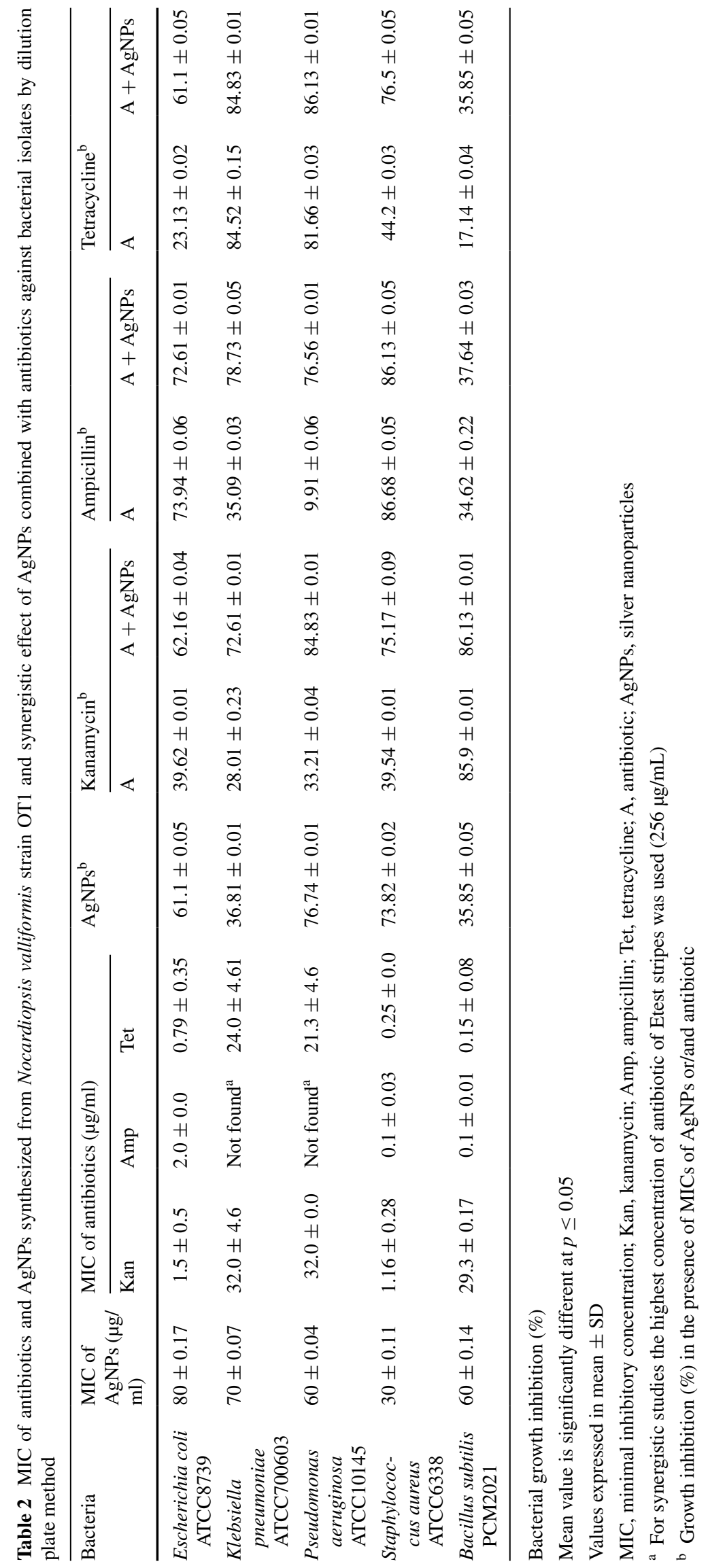




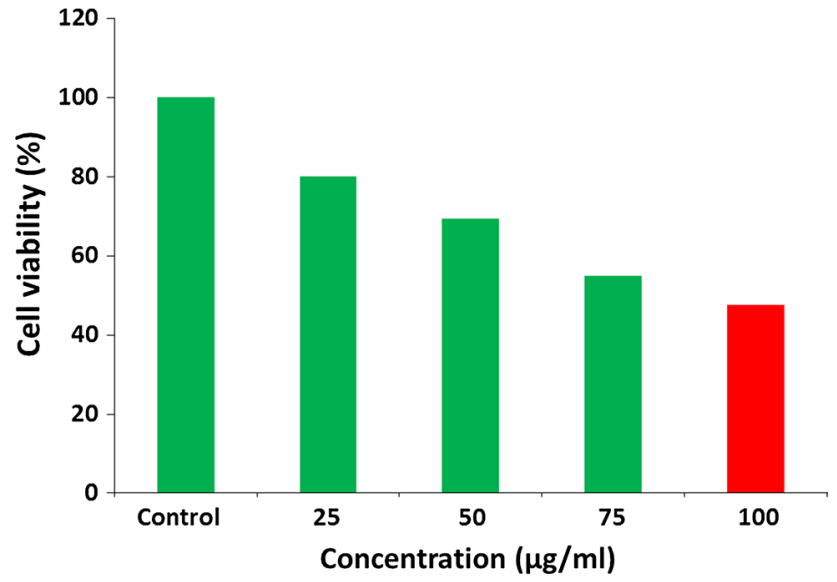

Fig. 8 Cytotoxicity of synthesized AgNPs from N. valliformis OT1 actinobacterial strain against cancer HeLa cell line

highest antibacterial activity. The antibacterial activity of silver nanoparticles also depends upon its shape [69].

Synergistic effect of antibiotics and silver nanoparticles to Gram-positive and Gram-negative bacteria provided helpful insight into the development of new antimicrobial agents with the enhancement of the antibacterial mechanism against pathogenic microorganisms. Such a mechanism was observed against almost all the tested bacterial pathogens after using disc diffusion method. However, the highest synergistic effect was observed for $K$. pneumoniae and $P$. aeruginosa when biosynthesized AgNPs from N. valliformis OT1 strain were combined with antibiotics. The bacteria were resistant to antibiotics alone (ampicillin and kanamycin, respectively). However, the application of biosynthesized AgNPs together with antibiotic enhanced the activity of ampicillin and kanamycin leading to inhibition of bacterial growth.

After using the dilution plate method the enhancement of growth inhibition of tested bacteria was variable when combination of AgNPs and antibiotics was used. The significant synergistic effect of AgNPs in combination with ampicillin or kanamycin was noticed against Klebsiella pneumoniae (41.92 and $35.8 \%$, respectively). The $8.09 \%$ enhancement of growth inhibition was observed in the presence of AgNPs and ampicillin against Pseudomonas aeruginosa. These findings support results of preliminary studies which have been carried out by disc diffusion method. Shahverdi et al. [70] who studied the combined effect of AgNPs and antibiotics found increase in antibacterial activity of antibiotics against bacterial cells. They claimed that synergism was caused by binding reaction between antibiotic molecules which showed hydroxyl and amino groups that may easily react with AgNPs. Similarly, our findings support results of Li et al. [71] who reported the synergistic antibacterial effects of antibiotic (amoxicillin) and silver nanoparticles.
The results of minimal inhibitory concentration confirmed that silver nanoparticles biosynthesized from $N$. valliformis OT1 strain were active against tested bacteria. Singh et al. [72] when studied MIC of AgNPs synthesised from Acinetobacter calcoaceticus reported activity of AgNPs against human pathogenic bacteria in much higher concentration range of $150-600 \mu \mathrm{g} / \mathrm{mL}$ as compared to our findings.

Cell culture-based assays are used as a pre-screening tool to understand the biological effects of nanoparticles. To detect the viability of cells, the method of Mosmann using the MTT colorimetric assay was performed. This assay is for measuring the activity of enzymes that reduce MTT or close dyes (XTT, MTS) to formazan, giving purple colour. The main application allows assessing the viability (cell counting) and the proliferation of cells (cell culture assay). It can be used to determine cytotoxicity of potential agent and toxic material, since those agents would stimulate or inhibit cell viability and growth [73].

The in vitro cytotoxic activity of silver nanoparticles was determined by MTT assay against cancer HeLa cells. We observed that the synthesized AgNPs inhibited the cell growth of cancer HeLa cell line. The biosynthesized AgNPs induced cytotoxicity in HeLa cell line in lower concentration $\left(\mathrm{IC}_{50}\right.$ at $100 \mu \mathrm{g} / \mathrm{mL}$ of $\mathrm{AgNPs}$ ) when compared to results by Manivasagan et al. [20] who reported the $\mathrm{IC}_{50}$ of HeLa cell line at concentration of $200 \mu \mathrm{g} / \mathrm{mL}$ of biosynthesized AgNPs from Nocardiopsis sp. MBRC-1.

$N$. valliformis strain OT1 was found to be simple, easy and eco-friendly system for the biological synthesis of AgNPs. The FTIR analysis showed the presence of protein as capping agent, which is responsible for stability of nanoparticles. The AgNPs were found to be small in size which may influence on its higher antibacterial activity [74]. Encouragingly, biosynthesized Ag-nanoparticles demonstrated remarkable antibacterial activity against bacterial pathogens as compared to commercially available antibiotics. On the basis of obtained results it seems that the combination of antibiotics with AgNPs against Gram-positive and Gram-negative bacteria offers a valuable contribution to nanomedicine. Similarly, the biogenic AgNPs demonstrated considerable cytotoxic effect on cancer HeLa cell line. Moreover, it can be suggested that the extreme habitats such as alkaline Lonar crater are still unexplored source of microorganisms which may produce bioactive compounds.

Acknowledgments This study was supported by Grant Symphony 1, No. 2013/08/W/NZ8/00701, from the Polish National Science Centre.

\section{Compliance with ethical standards}

Conflict of interest All authors declare that they have no conflict of interest. 
Ethical approval This article does not contain any studies with human participants or animals performed by any of the authors.

Informed consent Informed consent was obtained from all individual participants included in the study.

Open Access This article is distributed under the terms of the Creative Commons Attribution 4.0 International License (http://creativecommons.org/licenses/by/4.0/), which permits unrestricted use, distribution, and reproduction in any medium, provided you give appropriate credit to the original author(s) and the source, provide a link to the Creative Commons license, and indicate if changes were made.

\section{References}

1. Sondi I, Salopek-Sondi B (2004) Silver nanoparticles as antimicrobial agent: a case study on E. coli as a model for Gram-negative bacteria. J Colloid Interface Sci 275:177-182

2. Pal S, Tak YK, Song JM (2007) Does the antibacterial activity of silver nanoparticles depend on the shape of the nanoparticle? A study of the gram-negative bacterium Escherichia coli. Appl Environ Microbiol 27:1712-1720

3. Ingle A, Gade A, Pierrat S, Sönnichsen C, Rai M (2008) Mycosynthesis of silver nanoparticles using the fungus Fusarium acuminatum and its activity against some human pathogenic bacteria. Curr Nanosci 4:141-144

4. Bonde SR, Rathod DP, Ingle AP, Ade RB, Gade AK, Rai MK (2012) Murraya koenigii-mediated synthesis of silver nanoparticles and its activity against three human pathogenic bacteria. Nanosci Methods 1:25-36

5. Begum S, Hasan F, Hussain S, Ali-Shah A (2013) Prevalence of multi drug resistant Acinetobacter baumannii in the clinical samples from tertiary care hospital in Islamabad, Pakistan. Pak J Med Sci 29:1253-1258

6. Gupta A, Bonde SR, Gaikwad S, Ingle A, Gade AK, Rai M (2014) Lawsonia inermis-mediated synthesis of silver nanoparticles: activity against human pathogenic fungi and bacteria with special reference to formulation of an antimicrobial nanogel. IET Nanobiotechnol 8(3):172-178

7. Rai M, Ingle AP, Gade AK, Duarte MCT, Duran N (2015) Three Phoma spp. synthesised novel silver nanoparticles that possess excellent antimicrobial efficacy. IET Nanobiotechnol 9(5):280-287

8. Singh A, Prasad KN, Misra R, Rahman M, Singh SK, Rai RP, Tripathi A, Srivastava JK (2015) Increasing trend of heterogeneous vancomycin intermediate Staphylococcus aureus in a Tertiary Care Center of Northern India. Microb Drug Resist 21(5):545-550

9. Silver S (2003) Bacterial silver resistance: molecular biology and uses and misuses of silver compounds. FEMS Microbiol Rev 27:341-353

10. Cho KH, Park JE, Osaka T, Park SG (2005) The study of antimicrobial activity and preservative effects of nanosilver ingredient. Electrochim Acta 51:956-960

11. Gaikwad S, Ingle A, Gade A, Rai M, Falanga A, Incoronato N, Russo L, Galdiero S, Galdiero M (2013) Antiviral activity of mycosynthesized silver nanoparticles against herpes simplex virus and human parainfluenza virus type 3 . Int $\mathbf{J}$ Nanomed 8:4303-4314

12. Medici S, Peana M, Nurchi VM, Lachowicz JI, Crisponi G, Zoroddu MA (2015) Noble metals in medicine: latest advances. Coord Chem Rev 284:329-350

13. Chaudhari PR, Masurkar SA, Shidore VB, Kamble SP (2012) Effect of biosynthesized silver nanoparticles on Staphylococcus aureus biofilm quenching and prevention of biofilm formation. Int J Pharm Bio Sci 3:222-229

14. Priyaragini S, Sathishkumar SR, Bhaskararao KV (2013) Biosynthesis of silver nanoparticles using actinobacteria and evaluating its antimicrobial and cytotoxicity activity. Int $\mathrm{J}$ Pharm Pharm Sci 5(2):709-712

15. Saminathan K (2015) Biosynthesis of silver nanoparticles using soil actinomycetes Streptomyces sp. Int J Curr Microbiol Appl Sci 4(3):1073-1083

16. Shanmugaiah V, Harikrishnan H, Al-Harbi NS, Shine K, Khaled JM, Balasubramanian N, Kumar RS (2015) Facile synthesis of silver nanoparticles using Streptomyces sp VSMGT1014 and their antimicrobial efficiency. Dig J Nanomater Biostruct 10(1):179-187

17. Wolf-Rainer A (2016) Going beyond the control of quorumsensing to combat biofilm infections. Antibiotics (Basel) 5(1):3

18. Mallevre F, Fernandes TF, Aspray TJ (2016) Pseudomonas putida biofilm dynamics following a single pulse of silver nanoparticles. Chemosphere 153:356-364

19. Gandhiraj V, Sathish Kumar K, Madhusudhanan J, Sandhya J (2015) Antitumor activity of biosynthesized silver nano particles from leaves of Momordica charantia against MCF-7 cell line. Int J ChemTech Res 8(7):351-362

20. Manivasagan P, Venkatesan J, Senthilkumar K, Sivakumar K, Kim SK (2013) Biosynthesis, antimicrobial and cytotoxic effect of silver nanoparticles using a novel Nocardiopsis sp MBRC-1. Bio Med Res Int 2013:1-9. doi:10.1155/2013/287638

21. Supraja S, Arumugam P (2015) Antibacterial and anticancer activity of silver nanoparticles synthesized from Cynodon dactylon leaf extract. J Acad Ind Res 3(12):629-631

22. Li WR, Xie XB, Shi QS, Zeng HY, Ou-Yang YS, Chen YB (2010) Antibacterial activity and mechanism of silver nanoparticles on Escherichia coli. Appl Microbiol Biotechnol 85:1115-1122

23. Ramanathan R, O'Mullane AP, Parikh RY, Smooker PM, Bhargava SK, Bansal V (2011) Bacterial kinetics-controlled shapedirected biosynthesis of silver nanoplates using Morganella psychrotolerans. Langmuir 27:714-719

24. Rajamanickam U, Mylsamy P, Viswanathan S, Muthusamy P (2012) Biosynthesis of zinc nanoparticles using actinomycetes for antibacterial food packaging. In: International conference on nutrition and food sciences Singapore 39, IACSIT Press

25. Elbeshehy EKF, Elazzazy AM, Aggelis G (2015) Silver nanoparticles synthesis mediated by new isolates of Bacillus spp., nanoparticle characterization and their activity against Bean Yellow Mosaic Virus and human pathogens. Front Microbiol 6:453-465

26. Kushwaha A, Singh VK, Bhartariya J, Singh P, Yasmeen K (2015) Isolation and identification of $E$ coli bacteria for the synthesis of silver nanoparticles: characterization of the particles and study of antibacterial activity. Eur J Exp Biol 5(1):65-70

27. Sastry M, Ahmad A, Khan MI, Kumar R (2003) Biosynthesis of metal nanoparticles using fungi and actinomycetes. Curr Sci 85(2):162-170

28. Merin DD, Prakash S, Bhimba BV (2010) Antibacterial screening of silver nanoparticles synthesized by marine micro algae. Asian Pac J Trop Med 3(10):797-799

29. Tsibakhashvili NY, Kirkesali EI, Pataraya DT et al (2011) Microbial synthesis of silver nanoparticles by Streptomyces glaucus and Spirulina platensis. Nanomater Appl Prop 2:306-310

30. Aziz N, Faraz M, Pandey R, Shakir M, Fatma T, Varma A, Barman I, Prasad R (2015) Facile algae-derived route to biogenic silver nanoparticles: synthesis, antibacterial, and photocatalytic properties. Langmuir 31(42):11605-11612

31. Gade AK, Gaikwad SC, Tiwari V, Yadav A, Ingle AP, Rai MK (2010) Biofabrication of silver nanoparticles by Opuntia ficus indica: in vitro antibacterial activity and study of the mechanism involved in the syntheses. Curr Nanosci 6:370-375 
32. Iravani S (2011) Green synthesis of metal nanoparticles using plants. Green Chem 13:2638-2650

33. Rai M, Yadav A (2013) Plants as potential synthesizer of precious metal nanoparticles: progress and prospects. IET Nanobiotechnol 7(3):117-124

34. Arunachalam KD, Arun LB, Annamalai SK, Arunachalam AM (2015) Potential anticancer properties of bioactive compounds of Gymnema sylvestre and its biofunctionalized silver nanoparticles. Int J Nanomed 10:31-41

35. Golinska P, Wypij M, Rathod D, Tikar S, Dahm H, Rai M (2015) Synthesis of silver nanoparticles from two acidophilic strains of Pilimelia columellifera subsp. pallida and their antibacterial activities. J Basic Microbiol 55:1-16

36. Wrótniak-Drzewiecka W, Gaikwad S, Laskowski D, Dahm H, Niedojadło J, Gade A, Rai M (2014) Novel approach towards synthesis of silver nanoparticles from Myxococcus virescens and their lethality on pathogenic bacterial cells. Austin J Biotechnol Bioeng 1(1):7

37. Golinska P, Wypij M, Ingle AP, Gupta I, Dahm H, Rai M (2014) Biogenic synthesis of metal nanoparticles from actinomycetes: biomedical applications and cytotoxicity. Appl Microbiol Biotechnol 98:8083-8097

38. Bull AT (2010) Actinobacteria from the extremobiosphere. In: Horikoshi K, Antranikian G, Bull AT, Robb F, Stetter KO (eds) Extremophiles handbook. Springer, New York, pp 3-15

39. Antony CP, Kumaresan D, Ferrando L, Boden R, Moussard H, Fernández Scavino A, Shouche YS, Murrell JC (2010) Active methylotrophs in the sediments of Lonar Lake, a saline and alkaline ecosystem formed by meteor impact. Int Soc Microb Ecol 4:1470-1480

40. Borgave SB, Joshi AA, Kelkar AS, Kanekar PP (2012) Screening of alkaliphilic, haloalkaliphilic bacteria and alkalithermophilic actinomycetes isolated from alkaline soda Lake of Lonar, India for antimicrobial activity. Int J Pharm Biol Sci 3(4):258-274

41. Yang R, Zhang LP, Guo LG, Shi N, Lu Z, Zhang X (2008) Nocardiopsis valliformis sp. nov., an alkaliphilic actinomycete isolated from alkali lake soil in China. Int J Syst Evol Microbiol 58(7):1542-1546

42. Golinska P, Wang D, Goodfellow M (2013) Nocardia aciditolerans sp nov, isolated from a spruce forest soil. Anton Leeuw 103:1079-1088

43. Küster E, Williams ST (1964) Selection of media for isolation of Streptomycetes. Nature 202:928-929

44. Atlas RM (2004) Handbook of microbiological media, 3rd edn. CRC Press, Boca Raton

45. Shirling EB, Gottlieb D (1966) Methods for characterization of Streptomyces species. Int J Syst Bacteriol 16:313-340

46. Lane DJ (1991) 16S/23S rRNA sequencing. In: Stackebrandt E, Goodfellow M (eds) Nucleic acid techniques in bacterial systematic. Wiley, New York, pp 115-175

47. Kim OS, Cho YJ, Lee K et al (2012) Introducing EzTaxon-e: a prokaryotic 16S rRNA gene sequence data-base with phylotypes that represent uncultured species. Int J Syst Evol Microbiol 62:716-721

48. Tamura K, Stecher G, Peterson D, Filipski A, Kumar S (2013) MEGA6: Molecular evolutionary genetics analysis version 6.0. Mol Biol Evol 30:2725-2729

49. Guindon S, Gascuel O (2003) A simple, fast, and accurate algorithm to estimate large phylogenies by maximum likelihood. Syst Biol 52(5):696-704

50. Saitou N, Nei M (1987) The neighbor-joining method: a new method for constructing phylogenetic trees. Mol Biol Evol 4:406-425

51. Felsenstein J (1985) Confidence limits on phylogenies: an approach using the bootstrap. Evolution 39:783-791
52. Fitch WM (1971) Towards defining the course of evolution: minimum change for a specific tree topology. Syst Zool 20:406-416

53. Abdeen S, Geo S, Sukanya S, Praseetha PK, Dhanya RP (2014) Biosynthesis of silver nanoparticles from Actinomycetes for therapeutic applications. Int J Nano Dimens 5(2):155-162

54. Dougherty GM, Rose KA, Tok JBH, Pannu SS, Chuang FYS, Sha MY, Chakarova G, Penn SG (2008) The zeta potential of surface-functionalized metallic nanorod particles in aqueous solution. Electrophoresis 29:1131-1139

55. Rai M, Ingle A, Gade A, Duarte MCT, Duran N (2015) Synthesis of silver nanoparticles by Phoma gardeniae and in vitro evaluation of their efficacy against human disease-causing bacteria and fungi. IET Nanobiotechnol 9:71-75

56. Gaikwad SC, Birla SS, Ingle AP, Gade AK, Marcato PD, Rai M, Duran N (2013) Screening of different Fusarium species to select potential species for the synthesis of silver nanoparticles. J Braz Chem Soc 24(12):1974-1982

57. Mohanta YK, Behera SK (2014) Biosynthesis, characterization and antimicrobial activity of silver nanoparticles by Streptomyces sp SS2. Bioprocess Biosyst Eng 37:2263-2269

58. Prakasham RS, Buddana SK, Yannam SK, Guntuku GS (2012) Characterization of silver nanoparticles synthesized by using marine isolate Streptomyces albidoflavus. J Microbiol Biotechnol 22(5):614-621

59. Gole A, Dash C, Ramakrishnan V, Sainkar SR, Mandale AB, Rao M, Sastry M (2001) Pepsin-gold colloid conjugates: preparation, characterization, and enzymatic. Langmuir 17:1674-1679

60. Potara M, Bawaskar M, Simon T, Gaikwad S, Licarete E, Ingle A, Banciu M, Vulpoi A, Astilean S, Rai M (2015) Biosynthesized silver nanoparticles performing as imaging agents with anti-cancer activity against colon carcinoma C26 cell line. Colloid Surf B Biointerfaces 133:296-303

61. Chauhan R, Kumar A, Abraham J (2013) A biological approach to the synthesis of silver nanoparticles with Streptomyces sp. JAR1 and its antimicrobial activity. Sci Pharm 81:607-621

62. Gajbhiye M, Kesharwani K, Ingle A, Gade A, Rai M (2009) Fungus-mediated synthesis of silver nanoparticles and their activity against pathogenic fungi in combination with fluconazole. Nanomed Nanotechnol Biol Med 5:382-386

63. Udaya Prakash NK, Bhuvaneswari S, Prabha SB, Kavitha K, Sandhya KV, Sathyabhuvaneshwari P, Bharathiraja B (2014) Green synthesis of silver nanoparticles using airborne actinomycetes. Int J Chem Tech Res 6(9):4123-4127

64. Sukanya MK, Saju KA, Praseetha PK, Sakthivel G (2013) Therapeutic potential of biologically reduced silver nanoparticles from actinomycete cultures. J Nanosci 2013:1-8. doi: $10.1155 / 2013 / 940719$

65. Gordon O, Vig Slenters T, Brunetto PS et al (2010) Silver coordination polymers for prevention of implant infection: thiol interaction, impact on respiratory chain enzymes, and hydroxyl radical induction. Antimicrob Agents Chemother 54:4208-4218

66. Su HL, Chou CC, Hung DJ et al (2009) The disruption of bacterial membrane integrity through ROS generation induced by nanohybrids of silver and clay. Biomaterials 30:5979-5987

67. Yang W, Shen C, Ji Q, An H, Wang J, Liu Q, Zhang Z (2009) Food storage material silver nanoparticles interfere with DNA replication fidelity and bind with DNA. Nanotechnology 20(8):085102

68. Panacek A, Kvitek L, Prucek R, Kolar M, Vecerova R, Pizurova N, Sharma VK, Nevecna T (2006) Silver colloid nanoparticles: synthesis, characterization, and their antibacterial activity. J Phys Chem 110:16248-16253

69. Morones JR, Elechiguerra JL, Camacho A, Holt K, Kouri JB, Ramírez JT, Yacaman MJ (2005) The bactericidal effect of silver nanoparticles. Nanotechnology 16:2346-2353 
70. Shahverdi AR, Fakhimi A, Shahverdi HR, Minaian S (2007) Synthesis and effect of silver nanoparticles on the antibacterial activity of different antibiotics against Staphylococcus aureus and Escherichia coli. Nanomedicine 3:168-171

71. Li P, Li J, Wu C, Wu Q, Li J (2005) Synergistic antibacterial effects of $\beta$-lactam antibiotic combined with silver nanoparticles. Nanotechnology 16:1912-1917

72. Singh R, Wagh P, Wadhwani S, Gaidhani S, Kumbhar A, Bellare J, Chopade BA (2013) Synthesis, optimization, and characterization of silver nanoparticles from Acinetobacter calcoaceticus and their enhanced antibacterial activity when combined with antibiotics. Int J Nanomed 8(1):4277-4290

73. Weijia LI, Zhou J, Yuyin XU (2015) Study of the in vitro cytotoxicity testing of medical devices. Biomed Rep 3(5):617-620

74. Rai M, Yadav A, Gade A (2009) Silver nanoparticles as a new generation of antimicrobials. Biotechnol Adv 27:76-83 